\title{
EFIKASI SERBUK TUMBUHAN DALAM MENGENDALIKAN PENYAKIT BUSUK PANGKAL BATANG LADA DI LAPANGAN
}

\author{
Cipta Ginting ${ }^{1}$, Dad R.J. Sembodo², dan Herry Susanto ${ }^{2}$
}

\begin{abstract}
The efficacy of plant powder to control foot rot on black pepper in field condition. One of the problems in cultivating black pepper (Piper nigrum L.) is foot rot caused by Phytophthora capsici Leonian (P. palmivora MF4), that could kill the plants in only few days especially during rainy season. The objective of this experiment was to evaluate the efficacy of several plant powder to control the disease in semi-field condition. The experiment was conducted at the experiment station located at the campus of the University of Lampung from May to October of 2000. The semi-field condition was made by pushing a barrel into the soil to isolate the field soil as testing medium from the rest of the field soil. The treatments were arranged in a randomized complete block design with five replications and consisted of the rhizomes of Zingiber officinale, Alpinia galanga, and Kaempferia galanga, whole plant of Cymbopogon citratus and Elephantopus scaber, metalaxyl, and untreated control. To prepare the plant powder, each material was cut into small pieces then dried in oven at $50^{\circ} \mathrm{C}$ for 4 days and then ground in a blender. The powder was applied 3 days after inoculum infestation. The powder and inoculum was mixed with soil to the depth of $12 \mathrm{~cm}$ so that the soil contained $2 \%$ each. After one week, four plants were planted. As additional bioindicator to detect infective inoculum, eight leaf portions were pressed into the soil so that half of the leaf was bellowed the soil line. The plants were watered and observed daily. To determine viable fungal propagules, soil sample was taken weekly for five weeks. Soil assay was done with dilution technique using PDA supplemented with rosebengal. The results of the observation show that the treatments did not influence significantly the disease intensity on leaf portions or the whole plants. There were no significant differences on viable fungal propagules in soils received different treatments.
\end{abstract}

Key words: Piper nigrum, Phytophthora capsici, P. palmivora, inhibitory plant, botanical fungicide, Zingiber officinale, Alpinia galanga, Kaempferia galanga, Cymbopogon citratus, Elephantopus scaber, metalaxyl

\section{PENDAHULUAN}

Lada (Piper nigrum L.) merupakan salah satu tanaman perkebunan penting di Indonesia khususnya di Provinsi Lampung. Buahnya diperdagangkan dan digunakan secara luas di dalam negeri serta merupakan komoditas ekspor.

Salah satu masalah dalam budidaya lada ialah penyakit busuk pangkal batang yang disebabkan oleh Phytophthora capsici Leonian ( $P$. palmivora MF4). $P$. capsisi merupakan patogen tular tanah (soilborne), yang dapat ditularkan melalui tanah dan sintas (bertahan hidup) dalam tanah pada bagian tanaman yang terinfeksi. Sejak dilaporkan pertama kali di Sumatera Bagian Selatan pada tahun 1885, penyakit busuk pangkal batang (BPBL) sering menimbulkan kerugian yang sangat besar khsususnya pada musim hujan. Patogen dapat menyerang semua bagian tanaman termasuk akar, batang, dan daun. Kerusakan terparah biasanya terjadi jika infeksi terjadi pada pangkal batang (Semangun, 1988). Sukawa (1994) melaporkan bahwa di Lampung, kerusakan akibat penyakit sekitar 20\% tanaman lada, yang diperkirakan setara dengan kehilangan hasil 5.600 ton per tahun. Bahkan semua atau sebagian besar tanaman pada suatu kebun dapat mati jika cuaca mendukung perkembangan penyakit.

Penyakit BPBL dikendalikan dengan menggunakan bibit yang bebas dari inokulum, memelihara drainase, memberikan pupuk seimbang, memangkas naungan khususnya pada awal musim hujan, dan melaksanakan sanitasi. Selain itu, direkomendasikan beberapa fungisida seperti metalaksil, fosetil aluminium dan beberapa fungisida protektan. Akan tetapi, penyakit BPBL sejauh ini masih menjadi kendala utama dalam produksi lada karena gejala awal pada pangkal batang itu sulit diketahui dan dalam waktu singkat tanaman dapat mati. Lebih daripada itu, fungisida semakin mahal harganya dan sulit menentukan waktu aplikasi yang tepat serta tidak selalu efektif khususnya jika lingkungan sangat mendukung perkembangan penyakit (Manohara \& Kasim, 1996; Semangun, 1988).

\footnotetext{
${ }^{1}$ Dosen Jurusan Proteksi Tanaman Fakultas Pertanian Universitas Lampung.

2 Dosen Jurusan Budidaya Pertanian, Fakultas Pertanian, Universitas Lampung.
} 
Untuk meningkatkan keefektifan dan keefisienan pengendalian, disarankan agar penyakit dikendalikan secara terpadu (Sitepu \& Kasim, 1988; Manohara \& Kasim, 1996). Akan tetapi, pengendalian terpadu itu masih perlu dikembangkan agar lebih berhasil. Salah satu alternatif yang perlu diteliti ialah pemanfaatan serbuk tumbuhan sebagai fungisida nabati. Beberapa tumbuhan telah dimanfaatkan sebagai fungisida secara tradisional di Indonesia. Akan tetapi, topik itu perlu dikaji secara bersistem agar fungisida nabati itu dapat ditingkatkan menjadi teknologi pengendali hama dan penyakit yang efektif dan terpercaya (reliable) serta aman bagi manusia dan lingkungan hidup (Dhalimi dkk., 1999; Soehardjan, 1994).

Tujuan penelitian ini adalah untuk menilai efikasi beberapa serbuk tumbuhan dalam mengendalikan penyakit busuk pangkal lada di lapangan.

\section{METODE PENELITIAN}

Percobaan dilaksanakan di kebun percobaan di kampus Universitas Lampung dari Mei sampai Oktober 2000. Uji efikasi dilakukan di lapang dalam kondisi semi-lapang. Kondisi ini dibuat dengan menggunakan 'setengah drum' tanpa alas yang ditekankan sedemikian rupa sehingga sisi drum itu masuk $25 \mathrm{~cm}$ di bawah permukaan tanah untuk mengisolasi tanah tempat uji. Dalam percobaan ini, keefektifan serbuk tumbuhan menekan patogen dinilai dengan menggunakan dua jenis bioindikator, yaitu potongan daun berbentuk segitiga dan tanaman tanaman. Setiap drum dengan empat tanaman dan delapan potongan daun merupakan satu unit percobaan.

Ketujuh perlakuan, yang disusun dalam rancangan acak kelompok dengan lima ulangan, ialah rimpang jahe (Zingiber officinale), lengkuas (Alpinia galanga), dan kencur (Kaempferia galanga), seluruh tanaman serai wangi (Cymbopogon citratus) dan tapak liman (Elephantopus scaber), metalaksil, dan kontrol (tanpa serbuk atau fungisida). Metalaksil digunakan sebagai pembanding karena fungisida itu direkomendasikan untuk mengendalikan penyakit BPBL. Untuk menyiapkan serbuk, bagian tumbuhan untuk uji dipotong-potong, dikering-anginkan, dikeringkan lebih lanjut dalam oven pada suhu $50 \mathrm{C}$ selama 4 hari, lalu diblender.

Sementara itu, inokulum disiapkan dalam media tanah-oat seperti telah dilaporkan sebelumnya (Ginting dkk., 2001). Aplikasi serbuk dilakukan 3 hari setelah infestasi inokulum, yang dilakukan dengan menganduknya dengan tanah sedalam $12 \mathrm{~cm}$ sehingga tanah tersebut mengandung $2 \%$ masingmasing serbuk dan inokulum. Satu minggu kemudian, empat tanaman ditanam pada setiap drum. Sebagai bioindikator tambahan, delapan potongan daun berbentuk segitiga ditekankan ke dalam tanah sehingga setengah bagian daun masuk ke dalam tanah.

Setiap hari tanah disiram dan tanaman diamati. Sebagai peubah diamati keterjadian penyakit (disease incidence) pada daun lada, keparahan penyakit (disease severity) pada tanaman lada utuh, dan kepadatan propagul hidup jamur. Sampel tanah diambil setiap minggu sampai 5 minggu untuk menghitung kepadatan propagul jamur hidup dengan metode pengenceran (Johnson \& Curl, 1972). Media yang digunakan ialah PDA yang ditambahkan rosebengal, yang akan membatasi diameter koloni tanpa menghambat sporulasi jamur sehingga memudahkan pengitungan koloni jamur. Data hasil pengamatan dianalisis dengan sidik ragam dan uji Duncan $(\alpha=0,05)$.

\section{HASIL DAN PEMBAHASAN}

Hasil pengamatan terhadap daun lada menunjukkan bahwa sampai hari kelima tidak terdapat pengaruh perlakuan secara nyata terhadap keterjadian penyakit (Tabel 1). Pada hari keenam dan ketujuh, keterjadian penyakit pada daun lada dengan perlakuan metalaksil lebih rendah daripada penyakit pada daun dengan serbuk jahe. Selain itu, tidak terdapat perbedaan yang nyata antarperlakuan.

Pada Tabel 2 dicantumkan data keparahan penyakit pada tanaman lada 1-4 minggu setelah infestasi inokulum. Hasil pengamatan minggu ke-5 dan ke-6 sama dengan yang diperoleh pada minggu ke-4 itu. Data tersebut menunjukkan tidak terjadinya perbedaan nyata antarperlakuan, meskipun pada minggu pertama lima perlakuan cenderung menekan perkembangan penyakit (serai wangi, tapak liman, jahe, kencur, dan metalaksil).

Tabel 1. Keterjadian penyakit pada indikator daun lada pada tanah yang diberi perlakuan berbeda

\begin{tabular}{lccccc}
\hline Perlakuan & \multicolumn{5}{c}{ Keterjadian Penyakit (\%) $^{\mathbf{1}}$} \\
& \multicolumn{5}{c}{ 3-7 Hari setelah Inokulasi } \\
\cline { 2 - 6 } & $\mathbf{3}$ & $\mathbf{4}$ & $\mathbf{5}$ & $\mathbf{6}$ & $\mathbf{7}$ \\
\hline Kontrol & 10,0 a & 27,5 a & 30,0 a & 32,5 a & 35,5 a
\end{tabular}


C. Ginting dkk. : Efikasi serbuk tumbuhan dalam mengedalikan penyakit busuk pangkal batang lada

Kedua bioindikator menunjukkan persamaan dalam hal pengaruh metalaksil yang paling besar di antara semua perlakuan. Pada daun, metalaksil menekan penyakit secara nyata jika dibandingkan dengan pengaruh jahe; demikian juga pada tanaman, sampai akhir percobaan, hanya tanaman yang diberi perlakuan metalaksil yang tidak menunjukkan gejala penyakit. Di samping itu, pada daun dan tanaman lada masing-masing empat dan lima perlakuan nampaknya menunda perkembangan penyakit, meskipun secara statistik data itu tidak berbeda nyata.

Hal itu menunjukkan bahwa serbuk yang diuji mengandung senyawa yang menekan pertumbuhan jamur, namun dalam percobaan ini kurang efektif menekan patogen. Pemilihan bahan uji memang didasarkan atas seleksi awal dari 29 tumbuhan secara in vitro (Ginting dkk., 2000) dilanjutkan dengan uji efikasi 9 tumbuhan di laboratorium dengan menggunakan daun lada (Ginting dkk., 2001) dan uji efikasi rumah kaca dengan tanaman utuh (Ginting dkk., 2002) sehingga diperoleh lima tumbuhan untuk diuji di lapang. Banyak tumbuhan mengandung senyawa yang dapat menekan pertumbuhan jamur (misalnya, Balittro, 1994; Grainge \& Ahmed, 1988).

Demikian halnya kepadatan jamur, yang tidak berbeda nyata antarperlakuan (Tabel 3). Jamur dominan pada tanah itu ialah Trichoderma, Penicillium, dan Aspergillus. Setidaknya dapat dinyatakan bahwa dari data kepadatan propagul hidup jamur total itu belum tampak pengaruh nyata serbuk atau metalaksil terhadap jamur dalam tanah. Daya fungisida serbuk mungkin terlalu rendah dalam

Tabel 3. Kepadatan propagul hidup jamur pada tanah tempat pengujian serbuk

\begin{tabular}{lccccc}
\hline \multirow{2}{*}{ Perlakuan } & \multicolumn{5}{c}{ Kepadatan Jamur (x10 $\mathbf{C F U / g ~ T a n a h ) ~}{ }^{1}$} \\
\cline { 2 - 6 } & $\mathbf{1}$ & $\mathbf{2}$ & $\mathbf{3}$ & $\mathbf{4}$ & $\mathbf{5}$ \\
\hline Kontrol & 39,3 & 9,3 & 3,2 & 26,7 & 23,3 \\
Kencur & 18,7 & 11,2 & 3,3 & 19,3 & 29,9
\end{tabular}


menekan jamur tanah. Fungisida metalaksil merupakan 'fungisida sistemik' yang berspektrum sempit, yang hanya efektif menekan jamur Oomycetes seperti Pythium dan Phytophthora, dan jamur tepung (Agrios, 1997).

Riset ke arah pemanfaatan pestisida nabati biasanya dilakukan, khususnya di negara maju, dengan mengindentifikasi senyawa aktif dalam tumbuhan dan kemudian diproduksi senyawa kimia seperti itu secara buatan. Dalam riset seperti yang dilaporkan di sini, pendekatan yang diambil ialah menyeleksi tumbuhan yang efektif menekan pertumbuhan patogen secara in vitro yang kemudian dilanjutkan dengan uji efikasi di rumah kaca lalu ke lapang. Tujuan praktis dari penelitian ini ialah mengetahui prosedur aplikasi olahan sederhana seperti serbuk tumbuhan khsusunya dalam skala rumah tangga. Lebih daripada itu, jika terindentifikasi tumbuhan yang mengandung senyawa fungisida secara signifikan, dapat dipertimbangkan pemanfaatannya sebagai tumbuhan penutup tanah (cover crop) dalam kebun lada. Sejauh ini, lada sering dibudidayakan dengan olah tanah sempurna dengan tanah tanpa penutup. Hal ini mempermudah penyebaran inokulum di kebun. Dengan ditutupnya tanah dengan tumbuhan yang mengandung fungisida nabati itu, penyebaran patogen dipersulit, erosi dikurangi, dan bahan organik lepasan dapat menekan patogen sehingga mengurangi penyakit.

Dengan demikian, penelitian serupa ini perlu dilakukan pada waktu yang akan datang mungkin dengan perubahan dalam pendekatan yang diambil dan metode yang digunakan. Pada percobaan ini, intensitas penyakit baik pada daun maupun pada tanaman utuh relatif ringan termasuk yang menerima perlakuan kontrol. Pada percobaan sebelumnya, keterjadian penyakit pada daun kontrol di lab sebesar 78\% (Ginting dkk., 2001) dan pada tanaman lada utuh sebagai kontrol di rumah kaca sebesar 50\% (Ginting dkk., 2002). Dapat disarankan, dalam penelitian yang akan datang perlu diupayapan agar intensitas penyakit lebih tinggi. Pada penelitian ini, ringannya penyakit pada percobaan ini mungkin disebabkan karena pekerjaan ini dilaksanakan pada musim kemarau. Meskipun tanaman disiram setiap hari, kondisi lingkungan mungkin belum sepenuhnya mendukung perkembangan penyakit. Penyebab lain mungkin berkaitan dengan inokulum, yang di lapang banyak tertekan oleh faktor biologi, kimia, maupun fisik.

\section{SIMPULAN}

Data hasil pengamatan menunjukkan bahwa tidak terdapat serbuk tumbuhan yang mengurangi intensitas penyakit secara berarti baik pada potongan daun maupun pada tanaman. Demikian halnya pengaruh perlakuan terhadap kepadatan jamur, tidak terdapat perbedaan nyata antarperlakuan.

\section{SANWACANA}

Penelitian ini merupakan bagian dari penelitian dalam Proyek RUT VI. Kami mengucapkan terima kasih kepada LIPI, BPPT, dan Kantor Menristek. Demikian juga, atas bantuan teknis baik di laboratorium maupun di lapangan, kami menyampaikan terima kasih kepada Susi Yulianti, Lusi Inerce, Fima oktavia, Paryadi, dan Suhaimi. 


\section{DAFTAR PUSTAKA}

Agrios, G.N. 1997. Plant pathology. $4^{\text {th }}$ ed. Academic Press, Inc., San Diago.

Balittro. 1994. Prosiding seminar hasil penelitian dalam rangka pemanfaatan pestisida nabati. Bogor, 1-2 Desember 1994. Badan Penelitian dan Pengembangan Pertanian.

Dhalimi, A.D., D. Sitepu, \& D. Soetopo. 1999. Status dan perkembangan penelitian pestisida nabati. Makalah disampaikan pada Forum Komunikasi Ilmiah Pemanfaatan Pestisida Nabati. Bogor, 9-10 Nopember 1999. $12 \mathrm{hlm}$.

Ginting, C., D.R.J. Sembodo, H. Susanto, \& M.P. Yufdy. 2000. Kemampuan beberapa tepung tumbuhan dalam menekan pertumbuhan Phytophthora capsici dari tanaman lada. Dlm. Prosid. Kong. Nas. XV dan Sem. Ilmiah PFI. Purwokerto, 16-18 September 1999.

Ginting C., D.R.J. Sembodo, H. Susanto, \& M.P. Yufdy. 2001. Selected inhibitory plant powder reduced foot rot incidence on black pepper leaves in soil infested with Phytophthora capsici. In Proceed. International Congress and Symporium on Southeast Asian Agricultural Acience (IC-SAAS). Bogor, 6 - 8 November 2000.

Ginting, C., D.R.J. Sembodo, H. Susanto, \& M.P. Yufdy. 2002. Efikasi serbuk tumbuhan dalam mengendalikan penyakit pada lada akibat Phytophthora capsici. Dlm. Prosid. Kong. Nas. XVI dan Sem. Ilmiah PFI. Bogor, 22 - 24 Agustus 2001.
Grainge, M. \& S. Ahmed. 1988. Handbook of plant with pest-control properties. John Willey and Sons, New York.

Johnson, L.F. \& E.A. Curl. 1972. Methods for research on the ecology of soil-borne plant pathogens. Burgess Publishing Co. Minneapolis, MN.

Manohara, D. \& R. Kasim. 1996. Teknik pengendalian penyakit busuk pangkal batang tanaman lada. Hlm. 129-139 dalam Prosiding Seminar RISMC dan JICA, Bogor, 13-14 Maret 1996.

Semangun, H. 1988. Penyakit-penyakit tanaman perkebunan di Indonesia. Gadjah Mada University Press, Yogyakarta.

Sitepu, D. \& R. Kasim. 1988. Status of pepper diseases in Indonesia and their control strategy. Indust. Crops Res. J. 3:35-44.

Soehardjan, M. 1994. Konsepsi dan strategi penelitian dan pengembangan pestisida nabati. Hlm. 11-18 dalam Prosiding Seminar Hasil Penelitian dalam Rangka Pemanfaatan Pestisida Nabati. Bogor, 1-2 Desember 1994. Badan Penelitian dan Pengembangan Pertanian.

Sukawa, A. Br. 1994. Situasi perladaan di Lampung. Hlm. 33-42 dalam Prosiding Seminar Penelitian Tanaman Rempah dan Obat. Sub-Balittro Natar, Badan Penelitian dan Pengembangan Pertanian. 
Tabel 1. Keterjadian penyakit pada indikator daun lada pada tanah yang diberi perlakuan berbeda

\begin{tabular}{lrrrrr}
\hline \multirow{2}{*}{ Perlakuan } & \multicolumn{5}{c}{ Keterjadian Penyakit (\%) } \\
& \multicolumn{5}{c}{$\mathbf{3}-\mathbf{7}$ Hari setelah Inokulasi } \\
\cline { 2 - 6 } & \multicolumn{1}{c}{$\mathbf{4}$} & $\mathbf{5}$ & $\mathbf{6}$ & $\mathbf{7}$ \\
\hline Kontrol & $10,0 \mathrm{a}$ & $27,5 \mathrm{a}$ & $30,0 \mathrm{a}$ & $32,5 \mathrm{a}$ & $35,5 \mathrm{a}$ \\
Jahe & $10,0 \mathrm{a}$ & $50,0 \mathrm{a}$ & $57,5 \mathrm{a}$ & $62,5 \mathrm{a}$ & $70,0 \mathrm{a}$ \\
Tapak liman & $10,0 \mathrm{a}$ & $25,0 \mathrm{a}$ & $30,0 \mathrm{a}$ & $35,0 \mathrm{a}$ & $37,9 \mathrm{a}$ \\
Kencur & $2,5 \mathrm{a}$ & $17,5 \mathrm{a}$ & $22,5 \mathrm{a}$ & $35,0 \mathrm{a}$ & $32,0 \mathrm{a}$ \\
Lengkuas & $2,5 \mathrm{a}$ & $12,5 \mathrm{a}$ & $15,5 \mathrm{a}$ & $15,0 \mathrm{a}$ & $20,0 \mathrm{a}$ \\
Serai wangi & $2,5 \mathrm{a}$ & $15,5 \mathrm{a}$ & $27,5 \mathrm{a}$ & $30,0 \mathrm{a}$ & $35,0 \mathrm{a}$ \\
Metalaksil & $0,0 \mathrm{a}$ & $5,0 \mathrm{a}$ & $7,9 \mathrm{a}$ & $10,4 \mathrm{a}$ & $15,4 \mathrm{a}$ \\
\hline
\end{tabular}

${ }^{1}$ Angka yang diikuti huruf yang sama tidak berbeda nyata (uji Duncan, L = 0,05).

Tabel 2. Keparahan penyakit pada tanaman lada pada tanah yang diberi perlakuan berbeda

\begin{tabular}{lrrrr}
\hline \multirow{2}{*}{ Perlakuan } & \multicolumn{4}{c}{ Keparahan Penyakit (\%) } \\
& \multicolumn{1}{c}{$\mathbf{1}-\mathbf{4}$ Minggu setelah Inokulasi } \\
\cline { 2 - 5 } & $\mathbf{1}$ & \multicolumn{1}{c}{$\mathbf{2}$} & \multicolumn{1}{c}{$\mathbf{3}$} & \multicolumn{1}{c}{$\mathbf{4}$} \\
\hline Kontrol & 5,0 & 5,0 & 5,0 & 5,0 \\
Kencur & 5,0 & 5,0 & 9,0 & 10,0 \\
Serai wangi & 2,0 & 11,7 & 11,0 & 16,7 \\
Tapak liman & 0,0 & 10,0 & 10,0 & 10,0 \\
Jahe & 0,0 & 0,0 & 11,0 & 16,7 \\
Lengkuas & 0,0 & 0,0 & 4,0 & 5,0 \\
Metalaksil & 0,0 & 0,0 & 0,0 & 0,0 \\
\hline
\end{tabular}

${ }^{1}$ Angka yang diikuti huruf yang sama tidak berbeda nyata (uji Duncan, $\mathrm{L}=0,05$ ). Hasil pengamatan pada minggu ke-5 dan ke-6 sama dengan yang pada minggu ke-4. 
Tabel 3. Kepadatan propagul hidup jamur pada tanah tempat pengujian serbuk

\begin{tabular}{|c|c|c|c|c|c|}
\hline \multirow[t]{2}{*}{ Perlakuan } & \multicolumn{5}{|c|}{$\begin{array}{c}\text { Kepadatan Jamur (x10 }^{4} \text { CFU/g Tanah) }{ }^{1} \\
\text { 1- } 5 \text { Minggu Inokulasi }\end{array}$} \\
\hline & 1 & 2 & 3 & 4 & 5 \\
\hline Kontrol & 39,3 & 9,3 & 3,2 & 26,7 & 23,3 \\
\hline Kencur & 18,7 & 11,2 & 3,3 & 19,3 & 29,9 \\
\hline Serai wangi & 20,5 & 8,8 & 2,7 & 13,6 & 17,7 \\
\hline Tapak liman & 25,9 & 14,9 & 3,4 & 60,7 & 48,0 \\
\hline Jahe & 10,0 & 9,4 & 2,8 & 16,2 & 20,2 \\
\hline Lengkuas & 46,2 & 18,1 & 4,5 & 41,8 & 55,4 \\
\hline Metalaksil & 15,1 & 22,7 & 16,5 & 55,3 & 58,9 \\
\hline
\end{tabular}

${ }^{1}$ Pada setiap kolom, angka tidak berbeda nyata (uji Duncan, $\mathrm{L}=0,05$ ). 